\title{
Wage System of Female Worker Based on Putting Out System in Sidoarjo Regency
}

\author{
${ }^{1}$ LULUK FAUZIAH, ${ }^{2}$ MASHUDI, ${ }^{3}$ LELI IKA MARIYATI, ${ }^{4}$ LMI USROTIN CHOIRIYAH \\ ${ }^{1,4}$ Fakultas IImu Sosial dan Ilmu Politik, Universitas Muhammadiyah Sidoarjo, Jl. Mojopahit 666-B Sidoarjo, \\ ${ }^{2}$ Fakultas Ekonomi dan Bisnis, Universitas Muhammadiyah Sidoarjo, Jl. Mojopahit 666-B Sidoarjo, \\ Fakultas Psikologi, Universitas Muhammadiyah Sidoarjo, Jl. Mojopahit 666-B Sidoarjo,

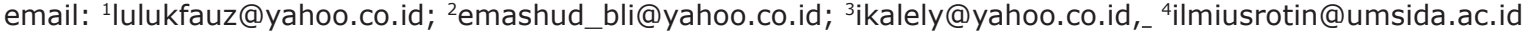

\begin{abstract}
The purpose of this study is to identify and analyze the wage system of female workers based on putting out system. The current study is located in Sidoarjo, East Java. The basic reason to choose Sidoarjo is due to its status as industrial district equipped with 2.635 large, medium, and small enterprises, including home industry that involves many female workers. Sidoarjo is also entitled to have the most Micro, Small, and Medium Enterprise (MSME) throughout Indonesia in 2015. The data was collected by in depth interview to key informants. Data analysis was done through the anticipation phase in the field that included data collection, data reduction, data display, and data verification referring to Data Management Analysis Methods proposed by Haberman \& Miles. Results of the study showed that the regional employment policy is inseparable with the policy from the central government. Wages are given directly by the owner with its value and amount received depends on the workpiece and deposited amount. The role from both government and NGO are not adequate.
\end{abstract}

Keywords: wage, female workers, putting out system

\section{Introduction}

Wages become a central point of conflict between workers and employers. For the workers, wage is the right in return for the services and the work that they contribute to achieve a final result in the form of objects or services. Wage is also a key component of income to ensure the lives of workers and their families, and also to improve the quality of their lives. Meanwhile for entrepreneurs, wage is the component of the cost of producing goods and services that can be reduced as much as possible. As Hafidhuddin (2008: 6) says that wage is often be an endless problem in industrial relations, regardless the form of legal entities and organizations within the enterprise. Wage is a complicated issue for the policy makers because of the demands of renewal and evaluation every year. It is even more complicate when the policy makers are confronted with the limited ability of companies to pay wages in accordance with the Regional Minimum Wage (UMR in Indonesia) and The City Minimum Wage (UMK) to the workers.

Some of the differences of wage between female and male is only explained by sexual discrimination (ILO, 2003). Discrimination is often reflected in different treatment and terms of employment, more females are hired on a part-time basis with or without contracts for a limited time or as wholesale workers. Such employment relations are very detrimental to the workers. Generally, they are paid daily without benefits and there is no certainty of job sustainability. Female's participation in the labor market increased significantly and discrimination against female workers is also a major problem. Most of female workers work in the nonformal sector. Education and training in the workplace is limited compared with to male

Received: February 06, 2017, Revision: April 06, 2017, Accepted: May 19, 2017

Print ISSN: 0215-8175; Online ISSN: 2303-2499.

Accredited by DIKTI. SK Kemendikbud, No.040/P/2014, valid 18-02-2014 until 18-02-2019, Indexed by DOAJ 
worker (Suyanto, 2006). The existence of female workers are absolutely bigger than male workers. Females are potentials to contribute and support the development process. The empowerment of women should be done as soon as possible, so that they can fill the development activities. That way, the assumption that they are only a burden of development can be eliminated. Female workers work in the industry sector based on putting out system that cannot be separated from the value and culture of gender division of worker which is already inherent in the society of Sidoarjo. The demands of female's role in the domestic are compatible to the work system because domestic and productive work can be done at once without having to leave home. There are efforts to enhance female's position as a subject of work by improving the policy related, but in practice the legality of employment relations between employers and workers has not been adequately regulated. This study aims to describe: (1) Condition of female workers in industrial sector; (2) The wage of female workers based on putting out system; (3) Factors that obstruct and support the wage of female based on putting out system in Sidoarjo regency.

\section{Wage Concept in Employment}

According to Sukirno (2010) the meaning of wage is "Payments for physical and mental services provided by the workers for the company." Thus in economic theory it is not distinguished between payments to worker services and preferential with payments to the non-permanent services. The definition of wage is contained in the ILO Convention on Protection of Wage. Indonesia follows these references with a little adaptation. The meaning of wage hold by the Indonesia is suitable to the Government Regulation no. 08 of 1981 concerning the Protection of Wage, which is an acceptance in return of the employer to the worker for a work or service which has been or will be done, declared or assessed in the form of money stipulated in accordance with an agreement or legislation, and paid on the basis of an employment agreement between employer and worker, including benefits for both the workers and their families (Suwarto, $2003 ; 188)$. Thus, wage is the worker rights and obligations of the employer, while on the other hand, the worker is obliged to give time, energy and mind to his/her work or provide services. In addition, Indonesia also holds "a provision" that wages have a social nature, where amount of wages and benefits should be able to fulfill the needs of the family.

\section{The Condition of Female Workers}

Women's Journal http:// jurnalperempuan.com (2011), found that there is a discrimination wage for female workers. Their wages are lower than male workers, they are considered single, they do not receive family benefits, and social guarantee for husband and children. In addition, they also have difficulties in getting promoted because they are always positioned lower than male even though their education and skills are higher. They are placed in jobs that require perseverance, thoroughness, neatness, and only do one type of work every day for years. These constraints cause violations of basic rights and obstruct female's opportunities in the world of work. Consequently, it will harm the society and economy of Sidoarjo including in Indonesia considering the contribution of women in the world of work is not recognized.

In the world of work, the provision of wage is a natural thing as a form of compensation for the contribution that given by the workers to the company. When a company recruits workers, they are expected to run a series of jobs to produce goods or services that support the business activities so it can give profits for the company. The profits used by the company to provide compensation in the form of wage to the workers. It means the existence of a worker within a company is in a framework of a partnership business and not a social activity. This is in line with the definition of wage in Act of The Republic of Indonesia Number 13 Year 2003 Concerning Manpower article 1 paragraph (30) about the employment that states: The wages are the rights of workers who are received and expressed in the form of money in return from employers to workers which have been determined and paid under an employment agreement, an agreement or legislation, including the benefits for workers and their families for a work or service that has been or will be done.

The contribution of workers to a company by performing their work can be called as performance or productivity. The better the performance and productivity, then the better wage they get than those workers who are low in performance and productivity. This is in accordance with Act 
of The Republic of Indonesia Number 13 Year 2003 Concerning Manpower article 92 paragraph (2) that states: Entrepreneurs conduct periodic wage review with regard to company capability and productivity. In the Minimum Wage Employment Regulation regulated by Minister of Regulation of the Manpower Minister No. Per-01/MEN/1999. In article 1 paragraph (1) mentioned that; The minimum wage is the lowest monthly wage consisting of basic wages including fixed benefits. The meaning of this minimum wage is a safety net towards the workers so that they would not be exploited in work and get a wage that can fulfill the Minimum Living Needs. The minimum wage applies only to single workers with a working period of less than one year.

\section{Gender Responsive Employment Policy}

Good governance criteria include equity, where all citizens of both male and female have an opportunity to improve their welfare (UNDP in LAN 2000:7). The gender responsive policy is essentially a manifestation of one of the principles of good governance. It is related to gender responsive policy which specifically consider fair policy benefits to female and male, either by age group (old-young), economic group (rich-poor) and marginal group (normal-disability).

Some strategies to implement policies to avoid gender refraction, according to Nugroho (2008:260-261) First, make sure the implementers understand that the policy is a pro-gender policy. Second, ensure that there is a reward and punishment mechanism for the obedient and the offender. Third, it has a pro-gender performance measure. Fourth, evaluate the performance, and the main requirements that must be fulfill are: (1) the existence of similarity conception about gender and gender equality; (2) the adequacy of the ability to conduct an evaluation in context of gender equality; ( 3 ) the evaluation tool itself should be able to reflect the reporting on the extent to which gender equality is achieved by a particular public policy. Meanwhile, Presidential Instruction Number 9 in 2000 on PUG in National Development states that the key components to the successful PUG are determined by: (1) The existence of political commitment and the government policy framework in supporting the development of gender perspective; (2) Human resources that have gender analysis skills and adequate funding sources; (3) Gender information system; (4) Monitoring and evaluation tools and systems, KIE media; and (5) community participation.

Related to the key components mentioned above, the increasing understanding and commitment of policy makers about the importance to mainstream the gender should be the main agenda, so that they realize that PUG should be the main strategy in realizing gender equality and justice in various fields of development. Thus, the process of formulating, implementing, monitoring and evaluating the development planning and budgeting become a gender responsive. If the policy makers understand and have a commitment about PUG, then they will produce gender responsive policies. Therefore, it is necessary to be supported by structural and functional institutions that have realization to embody gender equality and justice, the availability of data information system which is distinguished by sex and the ability of planners to develop gender responsive development planning. Finally, it is necessary to create space for community participation to take part in realizing gender equality and justice.

Development is very important for a country, especially for a developing country. Development is defined as a conscious effort made by the state and nation. In the implementation of national development, the worker has an important role and position as the agent and the purpose of development. In accordance with the role and position of worker, the development of employment is required to improve the quality of Indonesian people who would determine the success or failure of efforts to meet the takeoff stage. Improving the quality of Indonesian people will not be achieved without providing a guarantee of life to the workers and their families. In this life, a human being has diverse needs. In order to be able to fulfill all these needs, he/she is required to work, whether it is self-employed or working for others. Self-employed work on capital and self-responsibility, while working for others means working to those who give orders and workers must obey them.

A healthy employment should provides justice that can be accepted by all parties, from both a juridical point of view and general point of view, namely the protection of rights and interests of both parties suitable with the human dignity. In the implementation of the protection of workers, the government 
established Act of The Republic of Indonesia Number 13 Year 2003 Concerning Manpower to realize the welfare of workers and families. This is to ensure the basic rights of workers and equal opportunity and treatment without discrimination. According to Hafidhuddin (2008:23), fair/justice can be clear and transparent in meaning and guaranteed by the existence of clarity of contract (agreement) and commitment to be fulfilled by the parties of worker and entrepreneur, which can also be interpreted by the clauses governing during working relationship. Before workers are employed, there must be a clarity on how much workers earn and how to pay them.

Marginalization, in general, means removal. As it is stated by Irmayani et al $(2015 ; 479)$, to create an equality of roles between male and female, local genius has a very important role for public attitudes and participation. Socialization on concepts of gender understanding is needed for policy makers of Karo and South Nias government. Scott in Saptari and Holzner (1997) suggests that marginalization is a symptom of process and relative. Processing means that marginalization must be viewed on the basis of time. For example, if female fill certain sectors in the labor market, it must be seen how the previous situation and the changes that occurred after the "feminization" process. Relative means that the form of marginalization experienced by female should be compared with one that experienced by male. For example, in seeing the position of female in the labor market should also see the position of male in the same labor market. Gender refraction in wage occurs because the wage system uses male labor standards (Safa'at, 1998). Meanwhile, wage according to Central Statistic Agency (BPS) (Sakernas, 2003) is the acceptance of workers on the money or goods paid by company. Male refraction in the standard of Minimum Living Needs do not include women's needs such as underwear and sanitary napkins. In fact, a female worker must set aside $16 \%$ of her income each month for her specific needs (Nurmala in Safa'at, 1998). Income received by female workers is also lower because the status is considered single, although they have a family. In contrast to male who get facilities for wife and children, violence against the reproductive biology of female workers occurs when they are forced to work, although they have menstruating sickness due to the difficult furlough procedure and company wage system. In addition, female workers who are pregnant or have a baby can be exposed to the threat of layoffs.

\section{Research Methods}

This research uses descriptive qualitative and performed in natural setting. This method seeks to understand and interpret the meaning of an interaction event of human behavior in certain situations. Location of this research is in Sidoarjo Regency, with consideration: 1) Having 2635 of small, medium and large companies, it becomes the main target of job seekers both male and female. 2) As one of the districts that receive the award from the President in women's empowerment program. Primary data obtained through in-depth interview to the informants of 31 people. Informant determination was done by purposive sampling technique. In order to get maximum results from interview, researchers have arranged interview guide. Interview results are then transcribed, coded, and analyzed. The secondary data of the research were obtained from Local Regulation Document Number 8 in 2008 on employment services and development planning documents including: RPJPD, RPJMD, and RPJP, IPJ and IPM of Sidoarjo Regency.

The researchers use Gender Analysis Pathway (GAP) analysis method. This method is one of the gender analysis tools used to analyze the impact of development policies and programs on male and female. Furthermore, using GAP, policy planners can identify gender gaps and issues as well as development policy plans aimed to minimize gender gaps. With the identification of gender gaps and gender issues clearly, the development planning would be easier to be implemented compared to the previous one which was in general with the policy formulation of allegedly gender neutral.

\section{Results and Discussion:}

\section{Wage System}

The current labor situation with increasingly dynamics complex has put the wage as a major issue in developing countries such as Indonesia, including in Sidoarjo Regency. The dualistic labor market situation with the excess supply of worker and the low quality of the worker on the other hand causes wage becomes a central issue in the employment field. After the workers provide services to the company, the employer is required to provide compensation in 
accordance with the work that has been done by the workers. The benefits are commonly called wages and they are the main source of income for the workers. However, wage paying can sometimes bring out some problems. There are employers who pay too low wages to their workers with consideration that wages are only burden, where the higher wages paid to the workers the lower the profits they can get.

This wage policy basically consists of two major parts, namely: (1) Regulation related to wage determination mechanism; (2) Regulation related to wage protection. Regulations related to wage setting mechanisms are set forth in Act of The Republic of Indonesia Number 13 Year 2003 Concerning Manpower under the following system: (1) Determination of minimum wage at provincial \& district or city (Article 88 ); (2) Determination of wage through collective agreements (Article 91); (3) Implementation of structure and wage scale (article 92 paragraph 1); (4) Periodic Wage Review (Article 92 paragraph 2). Regulations related to wage protection are regulated in Act of The Republic of Indonesia Number 13 Year 2003 Concerning Manpower Article 88 paragraph 2 that says: To embody income that fulfills the living cost of humanity, the government establishes wage policy that protects workers. In addition to the regulation that organized in macro (in the form of Act of The Republic of Indonesia Number 13 Year 2003 Concerning Manpower), the government also makes the implementing rules in the form of government regulations, ministerial decrees and also in the form of ministerial regulations.

As stated by Baharudin (2015: 266), the cause of an enforcement of local governance is characterized by the implementation of accountable, transparent and participatory government. Public services mean an activity that gives amenity to the society in order to fulfill the interest according to the requirement of service recipients, either goods or service based on predetermined rules in order to satisfy the service recipient. While, according to Sinambela (2006:6) theoretically the purpose of public services basically to satisfy the society. To achieve the satisfaction, the quality of service is demanded and reflected in the transparency, accountability, and conditional. The service should be in accordance with the condition and the ability of the giver and the recipient of the service by sticking to the principle of efficiency and activity, participation, equality of rights and balance of rights and obligations. This is where the government's role in facilitating and protecting the society is needed especially related to the welfare of female workers.

\section{Problems Faced by Home Workers}

Home works or home workers experienced exploitation, in term that they work at their own homes for 24 hours a day and receive low paid, have no bargaining power and no also no job's certainty. The employers hire them to avoid responsibility, which is a violation against the Employment Act and at the same time transferring the risks and responsibilities that should have been the burden of the employers. Some striking characteristics of home workers are the uncondusive place to work, low wages, and there is no legal and social protection.

Labor unions regard home workers as a threat to the company's formal employment relationship. They should organize and advocate their rights and interests as workers. In general, the employers' stance are against anti-union workers due to the cases which considered that they have managed and negotiated for the higher wage demands. The efforts often backfired and caused the employers to simply shifting the production process to a village or other group of workers. Remembering that home workers work at their own homes and tend to be scattered, it would be difficult to find their location for the purpose of identifying and organizing.

\section{Wage-Based on Putting Out System in Sidoarjo District}

In Sidoarjo District, home work is a very difficult realm to be regulated and monitored effectively. Home work, also known as putting out system, is where female workers bring the work that should be done in the factory or company to their homes. In this case, the owner of the company gets free electricity and other risks including their working hours. This is what causes them to work outside the limits of working hours to pursue the target deposit. The more work done the more wages they receive. Wage-based putting out system has not been regulated in the Labor act. But in practice, there are many companies in Sidoarjo do the putting out system.

This provides an overview of the situation of home workers in Sidoarjo, how far the existing regulatory mechanisms can provide effective protection for women workers. This research analyzes on the 
current challenges to the implementation and enforcement of regulations for home workers and provides some suggestions to response the regulations made, especially on wage. The casualization of labor tendency often happens and contributes to the increasingly non-permanent and highly vulnerable forms of employment with violence such as home work. The difficulty in managing the problem is exacerbated by the fact that these highly vulnerable and non-permanent working are often unrecorded, so that there is no proper or effective oversight mechanisms over them. In other words, home workers are still regarded as 'invisible' workers.

Work relationship is basically the relationship between worker and employer after the employment agreement. The employment agreement is the beginning of an employment relationship created on the statement of the willingness between the worker and the employer. The work agreement may be done orally or written (Article 51 (1) of Act of The Republic of Indonesia Number 13 Year 2003 Concerning Manpower). Talking about legal protection means discussing rights and obligations related to the worker, and the rights after they did their obligations. In order to serve and implement regional development efficiently, effectively, democratically and to consider the participation of the society by considering the potentials, opportunities, obstacles and threats that may come in the future, the government of Sidoarjo Regency needs to analyze the strengths, weaknesses, opportunities and obstacles as in Table 1.

\section{Supporting and Obstacle Factors of Wage-based Putting Out System}

The condition of Sidoarjo Regency related to the wages of women workers

Table 1

SWOT Analysis of Social Service and Labor of Sidoarjo Regency

\begin{tabular}{|c|c|c|}
\hline No & Analysis & Explanation \\
\hline 1 & Strengths & $\begin{array}{l}\text { - Structure and work organization of Social Service and Labor } \\
\text { - Commitment of the leader in realizing the welfare of society and the quality } \\
\text { and fair of the workers } \\
\text { - Human resource quality, alert and responsive, (although in practice is not } \\
\text { maximal). } \\
\text { - Availability of government and private employment partners, such as; Kadin, } \\
\text { - Availability of government job exchange, private job exchange and special job } \\
\text { exchange that implement work placement. }\end{array}$ \\
\hline 2 & $\begin{array}{l}\text { Weak- } \\
\text { nesses }\end{array}$ & $\begin{array}{l}\text { - The principles of good government in the service of improving society's welfare } \\
\text { and employment is not yet optimized } \\
\text { - Quantity of HR functional position apparatus } \\
\text { - Lack of database availability of PMKS and employment } \\
\text { - The incomplete of social and labor legislation } \\
\text { - Unavailability of skilled labor. }\end{array}$ \\
\hline 3 & $\begin{array}{l}\text { Opportu- } \\
\text { nities }\end{array}$ & $\begin{array}{l}\text { - There is decentralization of the authority of the social and employment } \\
\text { - There is a job opportunity and expansion of work in informal sector } \\
\text { - There is a need for technical skills training and job seeker managerial to fill job } \\
\text { opportunities in the business and society } \\
\text { - Availability of training institutions of government, private and companies that } \\
\text { provide job training } \\
\text { - High interest of society and private sector in trade investing and services } \\
\text { industries } \\
\text { - Availability of community-based disaster preparedness cadets } \\
\text { - Availability of social welfare resource potentials }\end{array}$ \\
\hline 4 & Threats & $\begin{array}{l}\text { - The low wage of workers have raised the workers' layoffs } \\
\text { - Increased number of open unemployment due to additional new workforce, } \\
\text { layoffs and repatriation of migrant workers with problems } \\
\text { - The low motivation of the workforce for entrepreneurship due to limited } \\
\text { business capital and lack of market access } \\
\text { - The low quality and competitiveness of job seekers to fill job opportunities } \\
\text { - Increased urbanization of PMKS and workers. }\end{array}$ \\
\hline
\end{tabular}


based on putting out system, can be said as the element of regulation. One of the elements of assessment in determining regional employment policy is in terms of regulations; how the attitude of the government in providing welfare with a decent livelihood for themselves and their family, freedom of association for workers, social security workers, legal protection and non-discrimination for workers, both male and female.

From the institutional side, Dinsosnakertnas (Office of Social, Man Power and Transmigration) acts as the main actor that still facing the obstacles of the implementation of the labor policy which is not maximal yet especially related to the wage of workers especially in the industrial sector. Several factors that influence among others are: (1) unfinished employment profile; (2) Lack of funds, due to the limited budget used for the implementation of labor policy. It affects the two large areas which become the responsibility of Dinsosnakertrnas, consequently the implementation is not maximal; (3) Limited human resources (HR) of the implementer. As an illustration, Dinsosnakertrnas has 91 employees and only 26 of them have been educationally trained and the rest have not been trained in education; (4) Unavailability of professional trained labor required by the labor market; (5) There is still limited number of functional technical staff including supervisory and job-introduction personnel; (6) Lack of socialization of labor policy so that information does not spread because it is limited to the certain people only; (7) Less coordination of implementation, so that the implementation of employment policy seems partial and becomes Dinsosnakertrans affair only.

As it is understood, the new policy will produce a reality when followed by two other things, such as programs and projects (Brinkerhoff and Crosby, 2002), and without both of them, the employment policy is simply a sequence of words that yield no reality at all. These weaknesses will have impact on several partnership development program and coordination that should be developed by Dinsosnakertrans. Another impact is stuck on the office routine so that the activities outlined in the RPJMD 2004-2019 cannot be implemented properly. In addition, the existence of Regional Regulation Number 9 in 2008 on Employment Service is not known and understood by all people. Related to the contents of the policy, it only discusses the company's obligation on retribution to be issued by the company and does not discuss the worker affairs. Another factor which is also an obstacle related to the wage based putting out system is the interests and ownership of the company.

Efforts done by Dinsosnakertrans in achieving steps in policy implementation include: (1) Expanding employment opportunities to reduce unemployment and underemployment by providing employment for rural worker through Village Development Program; (2) Increasing guidance and use of worker effectively through Guidance and Use of Worker Program; (3) Guiding and improving vocational skills to be able to fill open employment opportunities in the development process through the Worker Education Program; (4) Guiding and improving harmonious worker relations and improving the protection of workers through the Protection Program of the Workers.

The policy-making process requires the policy makers to consider the existing resources as a supporting factor of implementation or obstruct policy implementation. There are groups or sources that previously considered as factors that disrupted the course of policy implementation, but in the end it provides support. Although under adverse conditions due to the limited competent apparatus, the Department of Social and Labor contributes to the implementation of the development of the employment field. Some programs have been done by the Department of Social and Labor which considered as supporter of the policy implementation. Implementation of Development in Sidoarjo Regency based on the Government Regulation of Indonesia Number 3 in 2007 that become the obligatory affairs are as follows: (1) Policies / programs / activities of employment field are directed to the training and skills to create trained and professional workers in order to fulfill the labor market, the optimization of employment institutions, and the improvement of worker welfare. The number of workers trained in various skills is constantly being upgraded to fulfill the labor market. Acceptance of received workers through the open labor market of Job Market Fair activity; (2) By the guidance of the Employment Supervisory Employee, the company's compliance with labor acts and regulations is also increasing, and proved by the decreasing number of working accidents. Thus, there is an increase for the company of 11 percent, and 14 percent for the worker; (3) The developing and strengthening of 


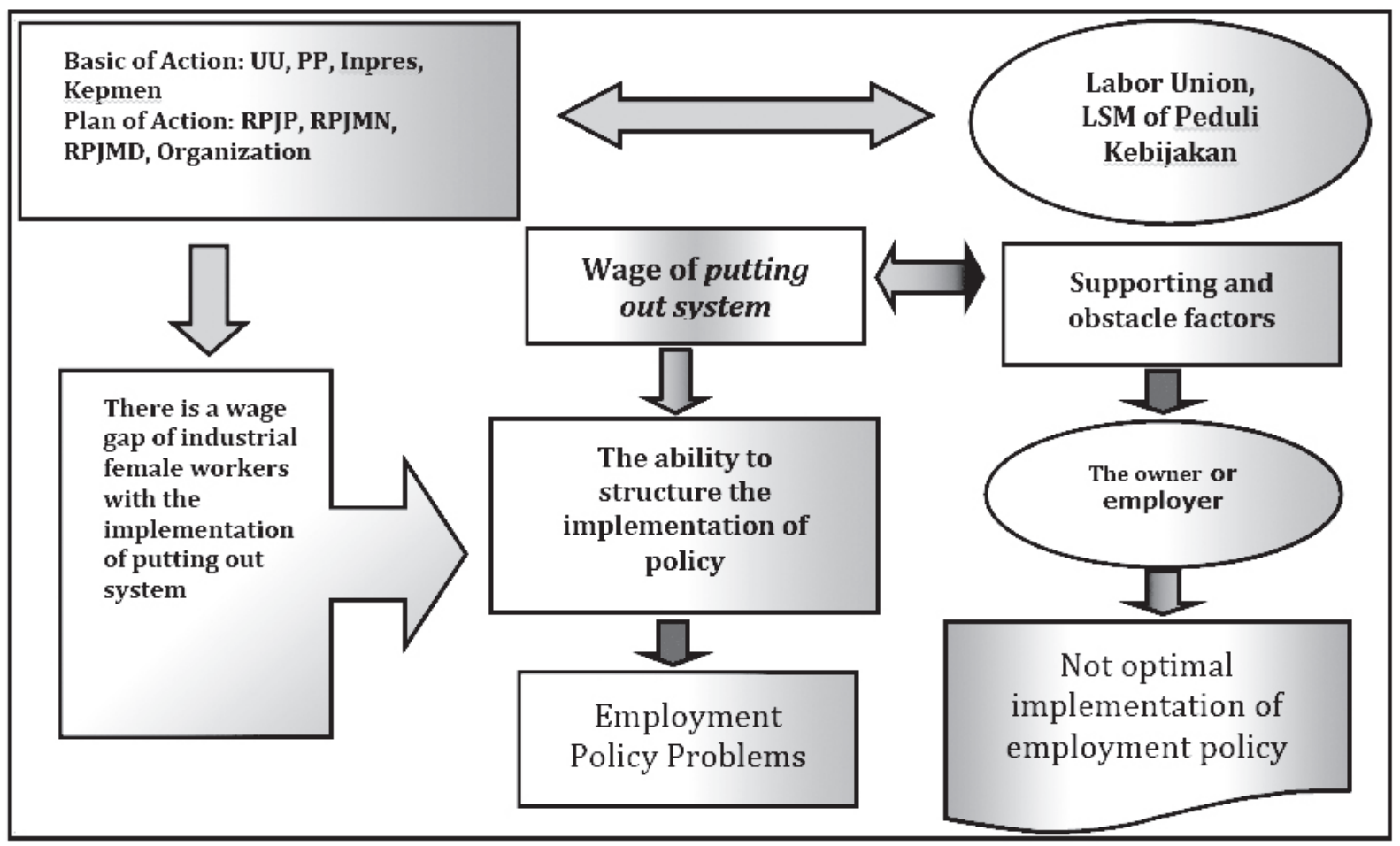

Figure 1: Wage Condition of Female Workers in Industrial Sector in Sidoarjo

information and database is implemented by doing data collection which distinguished male and female workers.

The concept of network governance which refers to a public problem-solving approach is no longer dependent on the State to make a decision, but arrange a problem-solving as an effort to support policy implementation. As Hajer and Wagenaar (2003) state, the key feature of network governance is the appreciation of the dependence and decreasing resources capacity that require the governments to engage with other actors. Regime governance needs the support and role of NGO (LSM) that are considered as important actors in multiactor interventions. They also have advocacy capacity and service delivery that emphasize the flexibility.

The specific needs of female workers are protected by Act of The Republic of Indonesia Number 13 Year 2003 Concerning Manpower, especially related to the maternity or biological abilities of female such as menstruation leave, maternity and breastfeeding leave. But the need is responded differently by each company depend on their policies with majority of them still put workers in a marginal position that does not have the strength to fight. Some female workers who work in the company say that it is very impossible for them to ask for maternity leave based on the regulations because in reality, the rules are set by the company. The same thing happens to the rules made for female workers based on putting out systems since they bring the work home, when they sick or else and can not finish the work they should have completed, they automatically will not get the wages. Overall, the results of the discussion above related to wages of workers/women workers based on Putting Out System in Sidoarjo Regency can be seen in the following figure 1

\section{Conclusions}

Based on the previous description, some conclusions and suggestions can be drawn as follows:

The condition of female workers based on putting out system in Sidoarjo have lower wages than those who work in the company. When it compared to male, female workers are considered single and do not get benefits for their family. Wages system of female workers based on putting out system experienced a very exploitative situation, where they worked for more than 24 hours and received under minimum wage. They have no bargaining power over them and no certainty of working continuity. 
From the institutional side, Dinsosnakertrnas as the main actor is still facing the obstacles of implementation of the labor policy which is implemented yet related to the wage of workers, especially in the industrial sector. Several factors influenced the matter and one of which is the limited human resources (HR) implementer. The supporting factor is the existence of Regional Act Number 8 in 2008 on the employment service although it does not regulate the rights and obligations of the company yet, and the development planning documents include: RPJPD, RPJMD, and RPJP, IPJ and IPM of Sidoarjo Regency that have accommodated the interests and needs of women in terms of development.

\section{References}

Act of The Republic of Indonesia Number 13 Year 2003 Concerning Manpower.

Baharudin. (2015). Akuntabilitas Pelayanan Publik: Studi Kasus Pelayanan Perizinan Mendirikan Bangunan di Kota Makasar. Jurnal MIMBAR. Volume 31, No. 2, (Desember 2015) 263-532. ISSN 02158175.

Brinkerhoff, Derick. W. and Crosby, Benyamin L. (2002). Managing Policy Reform: Concepts and Tools for Decision-Makers in Developing and Transitioning Countries. Kumarian Press. Bloomfield.

Hafidhuddin, Didin., and Tanjung, Henri. (2008). Sistem Penggajian Islam, Ctk. 1, Depok: Raih Asa Sukses.

Hak-hak Buruh (Pekerja) Perempuan, http:// jurnalperempuan.com/, (Diakses pada tanggal 16 September 2011, pukul 13.20).
Hasil Sensus Penduduk 2010, http://www.bps. go.id/ (Diakses pada tanggal 20September 2011, pukul 10.15).

ILO, (2003) Indonesia Implementation of National Social Security System Law (ILO Sub Regional Office for South East Asia). (http://jurnalperempuan.com) (2011),

LAN, and BPKP.(2003).Akuntabilitas dan Good governance, Modul/sosialisasi Sistem Akuntabilitas Kinerja Instansi Pemerintah (AKIP). Jakarta.

Nugroho, Riant. (2008). Gender dan Administrasi Publik. Yogyakarta: Pustaka Pelajar.

Regulation of the Manpower Minister No. Per01/MEN/1999.

Safa'at, Rachmad. (1998).Buruh Perempuan: Perlindungan Hukum dan Hak Asasi Manusia. Malang: Penerbit IKIP Malang.

Saptari, Ratna dan Brigitte Holzner. (1997). Perempuan, Kerja dan Perubahan Sosial: Sebuah Pengantar Studi Perempuan. Jakarta: Pustaka Utama Grafiti dan Yayasan Kalyanamitra.

Sukirno, Sadono. 2010. Pengantar Teori Ekonomi Makro Edisi Ketiga. Jakarta: Rajawali Pers.

Suwarto. (1998). Perlindungan Tenaga Kerja Perempuan; Kebijakan dan Implementasinya dalam Rachmad Safaat, (ed) Buruh Perempuan: Perlindungan Hukum dan Hak Asasi Manusia. IKIP Malang.

Irmayani, Tengku, dkk (2015), Local Genius dan Implementasi Pengarusutamaan Gender pada Pemerintahan Kabupaten di Sumatera Utara. Jurnal MIMBAR. Volume 31, No. 2, (Desember 2015) 263-532. ISSN 0215-8175. 